\title{
Plate tectonics from space
}

\begin{abstract}
Plate motion at the surface of the Earth can now be directly measured using space geodetic techniques. Measurements spread around the world are accumulating fast, and it is now possible to derive an accurate plate kinematics exclusively based on these space data. We discuss here a new map established at 1:50,000,000 scale summarizing the spectacular results of two decades of geodetic measurements pertinent to plate tectonics.
\end{abstract}

\section{Introduction}

Plate kinematics deals with the motion of tectonic plates at the surface of the Earth. These motions, although small at the human scale, are high enough at the geologic timescales to build mountains, open new oceans and recycle old ones at subduction zones. At the scale of the seismic cycle, these small motions are stored as elastic deformation at locked active faults, sometimes during centuries. The cumulated deformation is then suddenly released during large earthquakes as meter to tens of meters fault slip, as in the case of the Sumatra megathrust earthquake of December 2004.

In the early global plate models, "time" was introduced exclusively through the use of magnetic anomalies flanking the mid-oceanic ridges, correlated to the magnetostratigraphic timescale. Today, even small relative plate motions are captured by space geodesy, using GPS (Global Positioning System) and also other types of space techniques. The accuracy of the relative plate motion is now below the millimetre per year level. Satellite measurements of the Earth surface motion are accumulating fast, and a spectacular image of the horizontal displacements is emerging, solving plate kinematics enigma here and there and raising new questions elsewhere. We present here a new map that shows the current plate tectonics framework in the light of these new satellite measurements, superimposed onto a basemap obtained also from space techniques. Also shown in the background is a global plate model obtained from the combination of several regional geodetic networks. In the course of this work, we also carefully revisited plate boundaries, with special attention to areas of diffuse deformation not only over the continents, but also within the oceans.

\section{The plate tectonics revolution in the mid-1960s}

Plate tectonics was discovered in the mid-1960s. It merely originated from the exploration of the deep sea floor using oceanographic vessels. The crucial discovery was seafloor drifting at mid-oceanic ridges, and in particular the recognition of a symmetrical pattern of magnetic anomalies on their flanks. Their link with the creation of new oceanic floor was definitely interpreted as seafloor spreading where plates diverge (the Vine-Matthews hypothesis). The counterpart of plate divergence and new oceanic crust formation was plate convergence and consumption of (generally) old oceanic lithosphere at subduction zones, associated with deep sea trenches, large earthquakes (Wadati-Benioff zone) and volcanic belts (e.g. the Pacific fire ring). Outstanding young scientists (Jason Morgan, Xavier Le Pichon and Dan McKenzie) firmly established the basis of the plate tectonics theory - in which plate rigidity was a key element - allowing the calculation of the first global models of plate motion, known as plate "kinematics" (see the history of Plate Tectonics, in Le Pichon, 1991, the first global plate model in Le Pichon, 1968, and the seminal paper of Morgan, 1968).

Rates of motion in these models were exclusively derived from the distance of the oceanic magnetic stripes to the ridge where they were formed-divided by their age obtained by magnetostratigraphic correlations. One requirement was that a sufficiently long time had elapsed since their formation, so that their distance to the ridge axis was long enough to ease their identification as known magnetic chrons.
The modelled kinematics was thus an average over a time interval of about 3 million years, nowadays referred to as "geologic model" (DeMets et al., 1990 \& 1994). Plate tectonics was thus born from the sea, and the magnetic "barcode" remained our unique geological watch to measure plate velocities for the following decades until the advance of space geodesy.

\section{Plate motions from space geodesy}

The first artificial satellites were launched at approximately the same time (Sputnik, 1957). Without mentioning the bunch of applications unrelated to the progress of science, positioning was one useful output. However, few geoscientists in these early years would have bet a penny on the "real-time" detection of plate motions, these motions being considered as too small with respect to the large errors involved in ground station positioning. The unbelievable occurred in the $1980 \mathrm{~s}$, with the launch of the first GPS satellites constellation devoted to positioning and navigation: the accuracy was high enough to measure current plate motions. Aside to the 3 million years "geologic" watch, plate kinematics could now be measured over a time-span of a few years by measuring centimetre changes in ground stations positions. A new plate kinematics was thus established, exclusively based on satellite measurements (e.g. Sella et al., 2002; Kreemer et al., 2003).

The space-based models-now referred to as "geodetic models" - actually match the predictions of the conventional "geologic models" for a number of plates. Apart from delivering horizontal crustal motion at places where conventional geologic models failed, geodetic models allow to reassess major plate motions (steady-state motion) and ultimately discuss the evolution of these motion through time - in particular close to plate boundaries (transient deformations such as those related to the seismic cycle).

\section{The new map}

We briefly discuss below some of the elements of the new map.

\section{Localized boundaries}

The starting information is the plate boundaries version PB2002 (Bird, 2003) and the working set of plate boundaries from the PLATES Project (UTIG, see web link below). Ridges and transforms have been entirely redrawn. We used a combination of Harvard central moment tensor database $(<30 \mathrm{~km}$ depth), Engdahl relocated epicentres $(<30$ km depth, Mw > 5.0; Engdahl et al., 1998), bathymetry and small circles of plates relative motion. All earthquakes epicentres were georeferenced into several layers, although they are not shown in the final version of the map (see Figure 1 for example of superimposed seismicity layer). Whenever possible, we used high-resolution surveys and regional tectonic studies recently published and redrew the boundaries accordingly.

\section{Distributed boundaries}

Although they generally are, plates are not necessary bounded by localized faults. We did not try to force "plate boundary closing" at places where we do know that the exact boundary cannot be delimited - such as regions of very small relative motion between two adjacent plates (simply because their relative pole of rotation is there) or regions of true diffuse deformation. A classical example of slow motion is the North America-Eurasia relative motion in the Laptev Sea (Arctic) when approaching the location of the relative pole of rotation of those two plates (close to the Lena River delta, see Figure 1). Diffuse boundaries are widespread over the continental lithosphere, either as regions of diffuse compression (e.g. Mediterranean, Andean and Himalayan orogens, see Figure 2) or diffuse extension (e.g. Basin and Range Province, western Turkey). Although less studied, areas of diffuse compression and/or extension are also found over the oceanic lithosphere, such as the diffuse boundaries between India-Australia-Capricorn plates in the Indian Ocean, between North America and South America plates in the Central Atlantic Ocean, between Eurasia and 


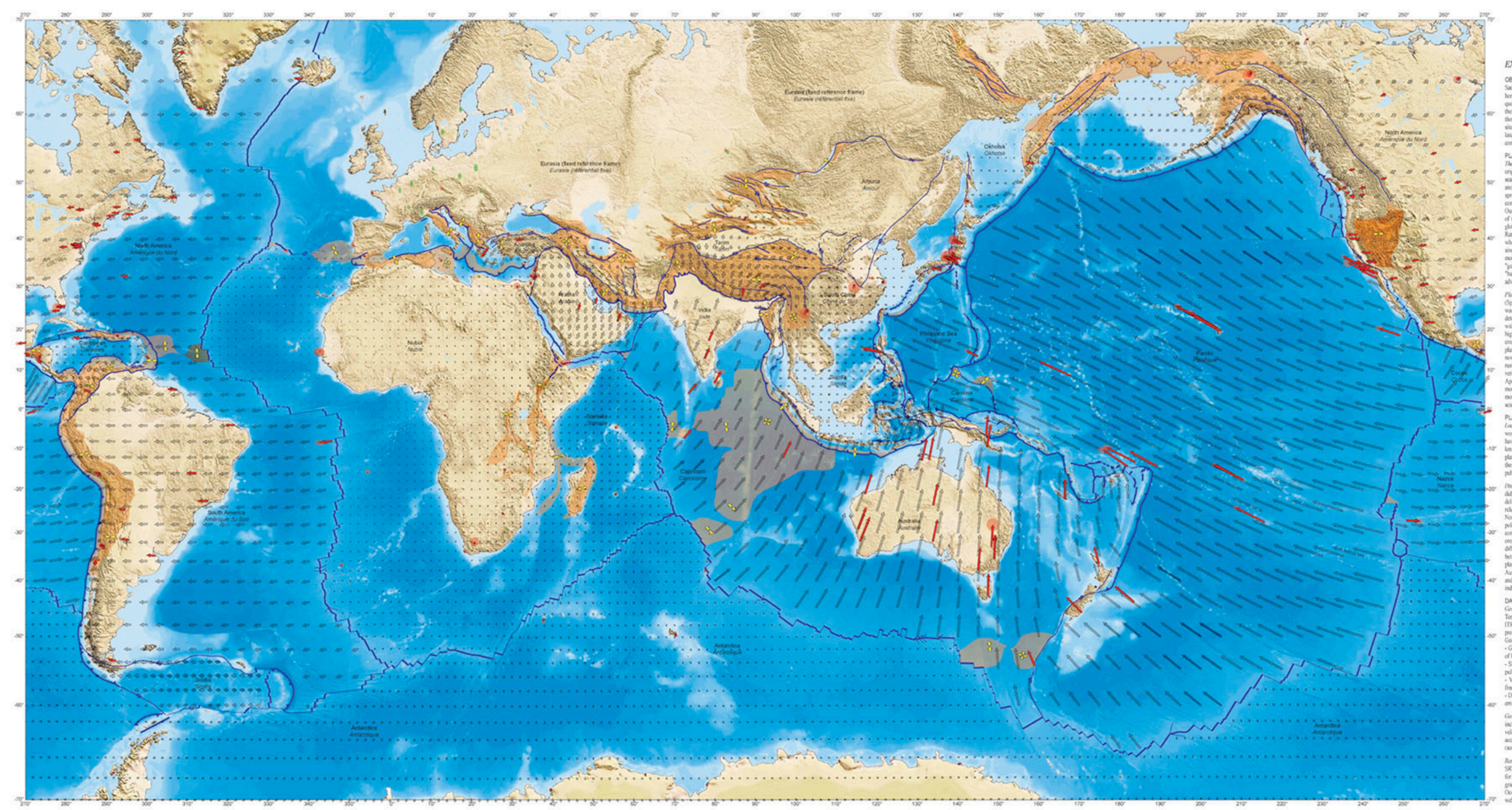

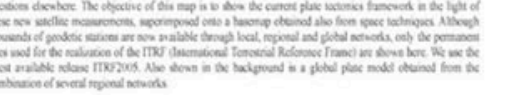

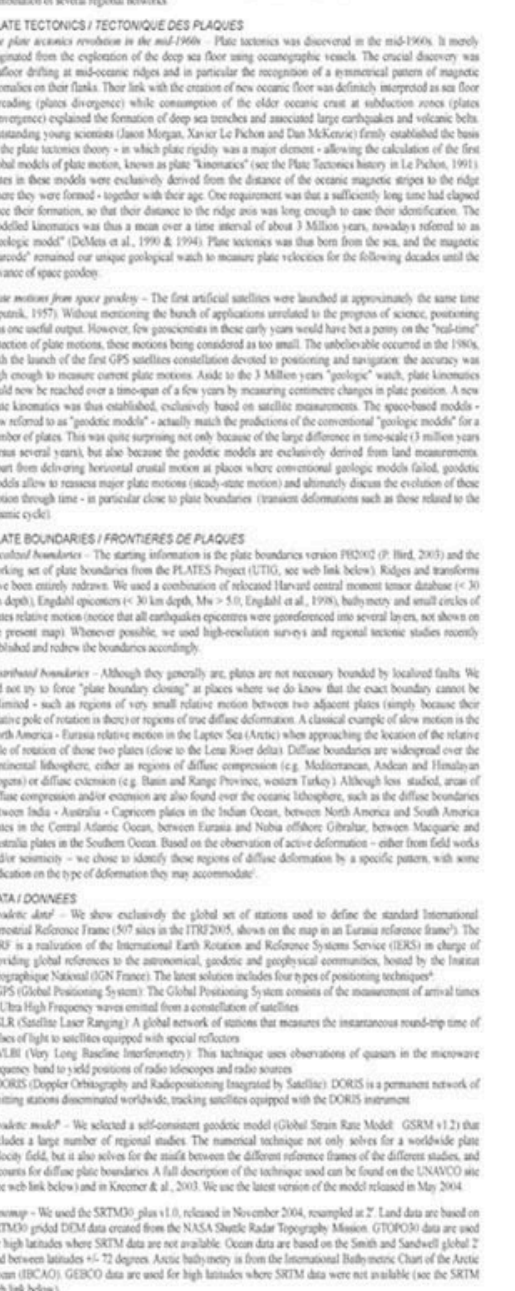

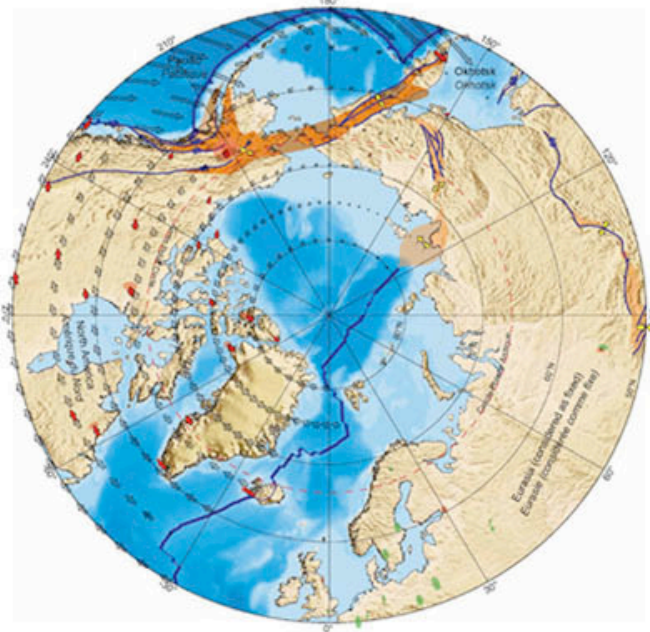
$\%_{s}=\begin{gathered}\text { PLATE TECTONICS FROM SPACE } \\ \text { En }\end{gathered}$

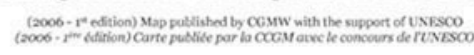

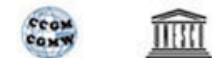

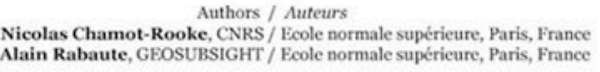

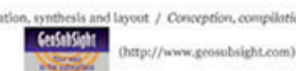

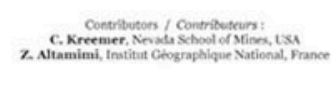

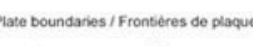

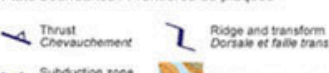

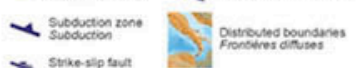

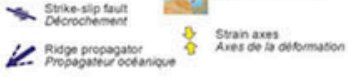

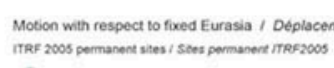

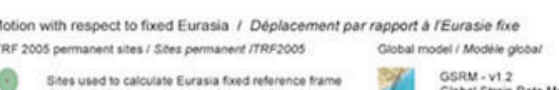
trats sate $>-\infty$ is

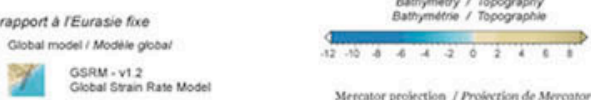

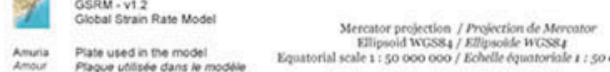

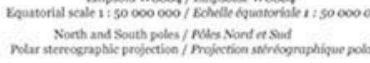

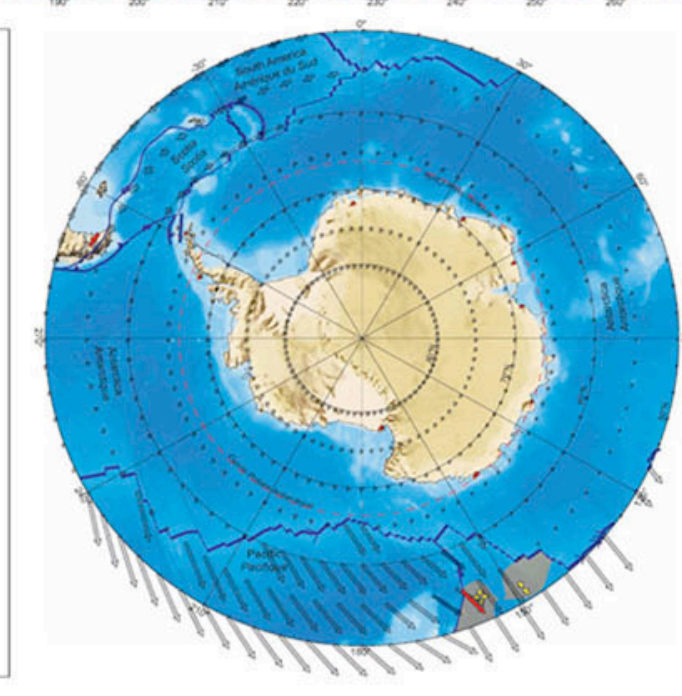

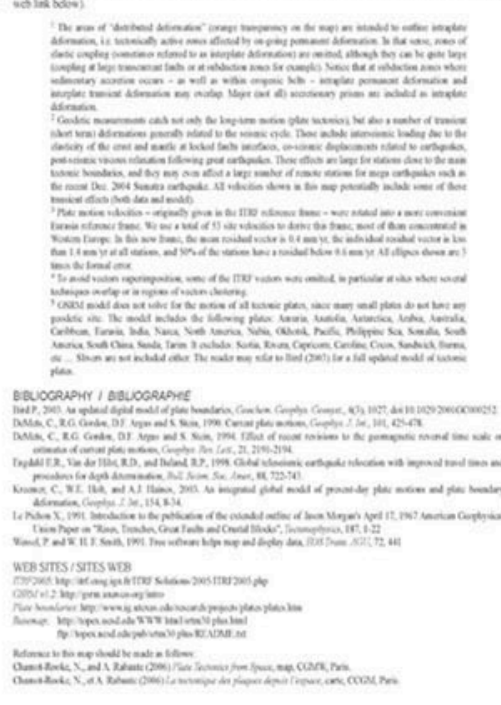




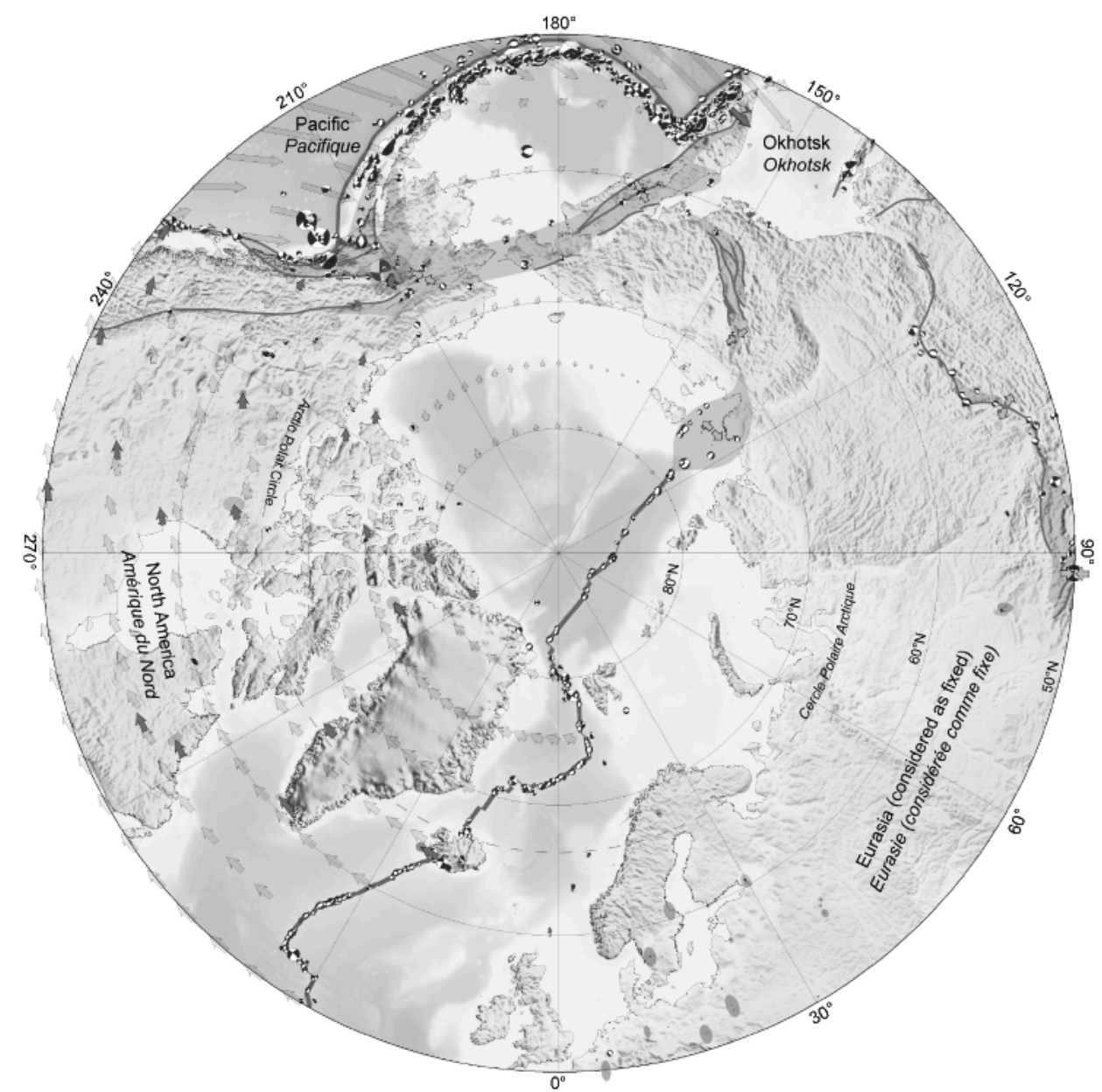

Figure 1 North Pole inset, including the seismicity (focal mechanisms) layer. Main tectonic boundaries are in blue. Orange transparency underlines zones of distributed deformation. Red arrows are measured motion with error ellipses (ITRF-2005 in an Eurasian frame of reference) and light arrows in the background are modelled velocities (GSRM model).

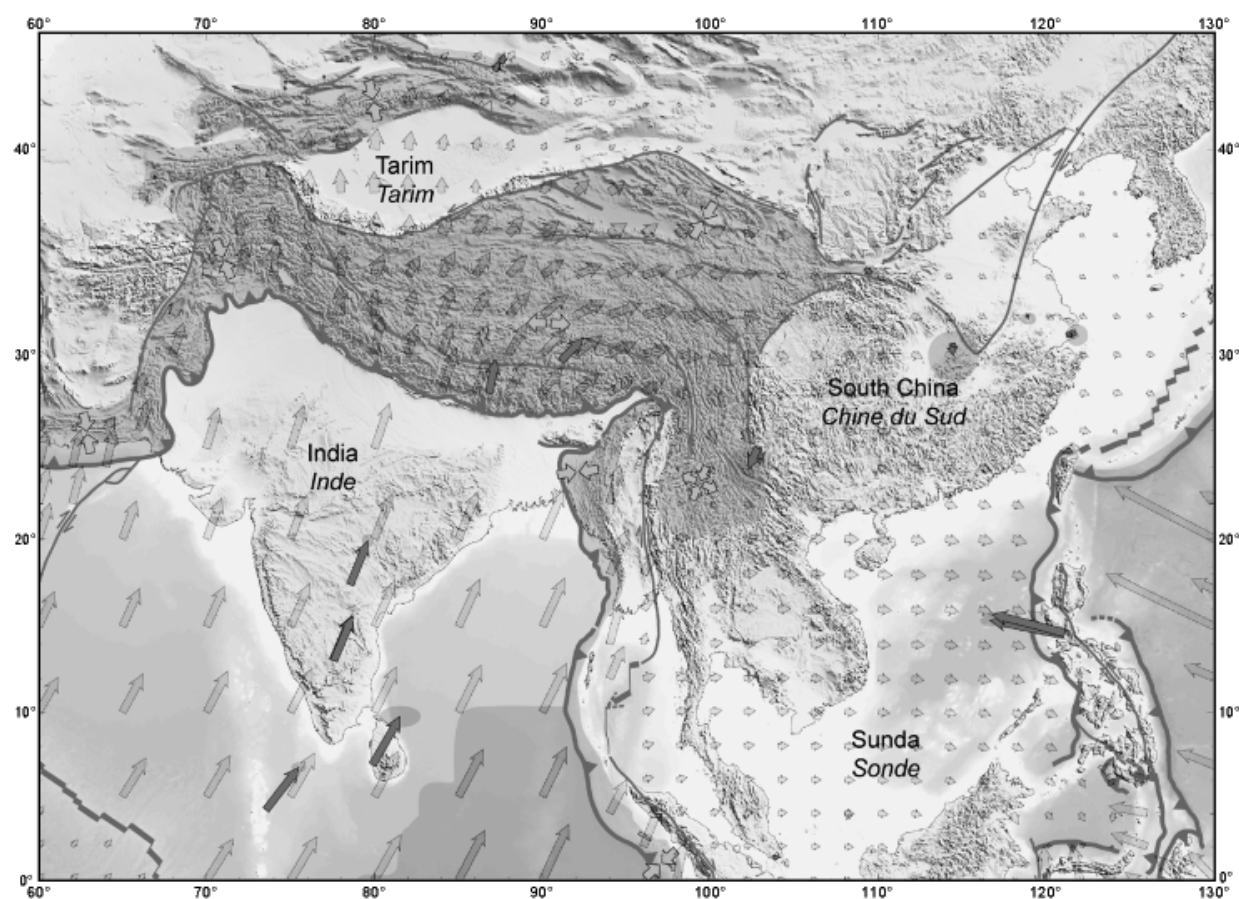

Figure 2 Zoom of the Himalayan collision belt. Notice the crustal flow around the eastern syntaxis channelled east of Tibet and west of the South China block, as well as the intraplate deformation in the Indian Ocean off Sumatra.
Nubia offshore Gibraltar, between Macquarie and Australia plates in the Southern Ocean. Based on the observation of active deformation - either from field works and/or seismicitywe chose to identify these regions of diffuse deformation by a specific pattern, with some indication on the type of deformation they may accommodate.

The areas of "distributed deformation" (orange transparency on the map) are intended to outline intraplate deformation, i.e. tectonically active zones affected by on-going permanent deformation. In that sense, zones of elastic coupling (sometimes referred to as interplate deformation) are omitted, although they can be quite large (coupling at large transcurrent faults or at subduction zones for example). Notice that at subduction zones where sedimentary accretion occurs - as well as within orogenic belts - intraplate permanent deformation and interplate transient deformation overlap. Major (not all) accretionary prisms are included as intraplate deformation.

\section{Geodetic data}

We show exclusively the global set of stations used to define the standard International Terrestrial Reference Frame (507 sites in the ITRF2005, shown on the map in an Eurasia reference frame). The ITRF is a realization of the International Earth Rotation and Reference Systems Service (IERS) in charge of providing global references to the astronomical, geodetic and geophysical communities, hosted by the Institut Géographique National (IGN France). The latest solution includes four types of positioning techniques:

- GPS (Global Positioning System): The Global Positioning System consists of the measurement of arrival times of Ultra High Frequency waves emitted from a constellation of satellites.

- SLR (Satellite Laser Ranging): A global network of stations that measures the instantaneous round-trip time of pulses of light to satellites equipped with special reflectors.

- VLBI (Very Long Baseline Interferometry): This technique uses observations of quasars in the microwave frequency band to yield positions of radio telescopes and radio sources.

- DORIS (Doppler Orbitography and Radiopositioning Integrated by Satellite): DORIS is a permanent network of emitting stations disseminated worldwide, tracking satellites equipped with the DORIS instrument. 
To avoid vectors superimposition, some of the ITRF vectors were omitted, in particular at sites where several techniques overlap or in regions of vectors clustering.

\section{Frame of reference for geodetic vectors}

Plate motion velocities - originally given in the ITRF reference frame-were rotated into a more convenient Eurasia reference frame. We use a total of 53 site velocities to derive this frame, most of them concentrated in Western Europe. In this new frame, the mean residual vector is $0.4 \mathrm{~mm} / \mathrm{yr}$, the individual residual vector is less than 1.4 $\mathrm{mm} / \mathrm{yr}$ at all stations, and $50 \%$ of the stations have a residual below 0.6 $\mathrm{mm} / \mathrm{yr}$. These numbers are quite representative of the type of accuracy that is reached today. All ellipses shown are 3 times the formal error.

\section{Geodetic model}

We selected a self-consistent geodetic model (Global Strain Rate Model: GSRM v1.2) that includes a large number of regional studies. The numerical technique not only solves for a worldwide plate velocity field, but it also solves for the misfit between the different reference frames of the different studies, and accounts for diffuse plate boundaries. A full description of the technique used can be found on the UNAVCO site (see web link below) and in Kreemer \& al., 2003. We use the latest version of the model released in May 2004. The GSRM model does not solve for the motion of all tectonic plates, since many small plates do not have any geodetic site. The model includes the following plates: Amuria, Anatolia, Antarctica, Arabia, Australia, Caribbean, Eurasia, India, Nazca, North America, Nubia, Okhotsk, Pacific, Philippine Sea, Somalia, South America, South China, Sunda, Tarim. It excludes: Scotia, Rivera, Capricorn, Caroline, Cocos, Sandwich, Burma, etc. ... Slivers are not included either. The reader may refer to Bird (2003) for a full updated model of tectonic plates.

\section{Basemap}

We used the SRTM30_plus v1.0, released in November 2004, resampled at 2'. Land data are based on SRTM30 grided DEM data created from the NASA Shuttle Radar Topography Mission. GTOPO30 data are used for high latitudes where SRTM data are not available. Ocean data are based on the Smith and Sandwell global 2' grid between latitudes +/- 72 degrees. Arctic bathymetry is from the International Bathymetric Chart of the Arctic Ocean (IBCAO). GEBCO data are used for high latitudes where SRTM data were not available (see the SRTM web link below)

\section{Discussion}

Perhaps the most unexpected result is the general agreement of the geodetic motions with the predicted geological motions obtained previously through conventional global plate models. According to global geodetic models, the geodetic motion of two thirds of plate pairs agrees with the NUVEL-1A geologic velocities within uncertainties (Crétaux et al., 1998; Sella et al., 2002). This was quite surprising not only because of the large difference in time-scale ( 3 million years average for the geologic models versus several years for the geodetic models), but also because the geodetic models are exclusively derived from land measurements. The conclusion is that the motion of many of the plates remained stable through time for at least the last 3 million years. Quite interestingly, a few plates show definitively different motions. We exclusively discuss here the plates for which recent literature points to significant discrepancies not related to errors in the models. Differences may indeed arise because of poor constraints in the geological model-such as plates surrounded mainly by subduction (Philippine Sea plate, Sunda plate, Caribbean plate...) - or poor constraints in the geodetic model (e.g. purely marine plates, with a small number of geodetic stations). One of the most significant differences relates to plates involved in the Himalayan belt sensu lato: the geodetic motion of Nubia (Africa), Arabia and India relative to Eurasia seems to be at least $20 \%$ slower than the 3 million year average (Socquet et al., 2006; Calais et al., 2003). In the case of Nubia/Eurasia, the direction of motion itself seems to be significantly deviated. These differences are interpreted as true long-term deceleration in plate convergence (Vigny et al., 2006).
Plate rigidity $-\mathrm{a}$ fundamental requirement of the plate tectonics hypothesis-can be re-evaluated using these new geodetic measurements. A measure of the deformation in plate interiors is the misfit to a rigid-plate rotation for one given plate. The best test is probably the Eurasian plate, in particular its western portion which is uniformly covered by permanent stations measured for one to two decades. Taking the mean of the residual vectors quoted above $(0.4 \mathrm{~mm} / \mathrm{yr})$ over distances that reach at least $2500 \mathrm{~km}$, the geodetic rate of deformation for Eurasia is $2 \times 10^{-10} \mathrm{yr}^{-1}$. This value merely reflects the current resolution of the geodetic measurements, since smaller rates of deformation are probably not yet detected due to errors inherent to the space techniques. Still, this rate is one to two orders of magnitude less than the rate which is actually measured in actively deforming regions. Intraplate deformation of the oceanic lithosphere is 50 times larger (Delescluse and Chamot-Rooke, 2007), and intraplate deformation in the Himalayas is 200 times greater (Calais et al., 2006). Geodetic strain in plate interiors is thus confirmed to be small. Note that even at these small rates, plate interiors may experience infrequent but large earthquakes due to long period of strain accumulation.

Densification of the geodetic networks in active continental settings provides spectacular views of the crustal dynamics. Escape of the Anatolian microplate sideway of the Arabia-Eurasia collision (Mc Clusky et al., 2000; Kreemer and Chamot-Rooke, 2005) and crustal flow around the eastern syntaxis of the Himalayas (Wang et al., 2001; Shen et al., 2005) are particularly well documented (see Figure 2). The obtained continental kinematics is a key element to discuss some of the fundamental earth deformation problems: distributed versus localized deformation in mountain belts (Holt et al., 2000; England and Molnar, 2005), degree of coupling between deep ductile layers and upper brittle crust (Flesch et al. 2005; Shen et al., 2005), origin of the forces that drive plate tectonics (Flesch et al., 2001; Gosh et al., 2006).

Geodetic measurements catch not only the long-term motion (plate tectonics), but also a number of transient (short term) deformations generally related to the seismic cycle. These include interseismic loading due to the elasticity of the crust and mantle at locked faults interfaces, co-seismic displacements related to earthquakes, post-seismic viscous relaxation following great earthquakes. Measurements of the interseismic deformation allow reassessing the present-day motion across many of the continental active faults, and comparisons with their Holocene rates obtained from geological markers open a new field for faults studies. Discrepancies between geodetic and geological slip rates are tentatively interpreted as true variability through time. GPS measurements of the post-seismic relaxation also shed new light on the deep crustal and mantle rheology. These effects are large for stations close to the main tectonic boundaries, and they may even affect a large number of remote stations for the mega earthquakes such as the recent Dec. 2004 Sumatra earthquake (Vigny et al., 2005). All velocities shown in this map potentially include some of these transient effects (both data and model).

\section{Conclusions}

This new map is a first step towards the integration of space measurements into a modern geodynamic framework. We deliberately choose to show the permanent sites only, those that are actually used to calculate the International Terrestrial Reference Frame of the geodesists. Local and regional GPS networks are being developed in many places of the world, multiplying the number of ground stations available for future occupations. The next challenge is to integrate these networks into one single coherent frame of reference for a future edition of the map.

\section{Acknowledgements}

We thank Corné Kreemer (Nevada School of Mines, USA) for his expertise on the GSRM kinematic model, and Zuheir Altamimi (Institut Géographique National, France) for providing us with the latest release of the geodetic ITRF-2005 solution. Philippe Rossi and Jean-Paul Cadet are warmly thanked for their enthusiastic support in the course of the project, Philippe Bouysse for his careful review of early versions of the map, and Bruno Vrielynck for his help on the Caspian Sea bathymetry. 
A.R. was supported by the Commission for the Geological Map of the World. Geosubsight is a young innovative company incubated by Agoranov. Maps were prepared with the GMT software (Wessel and Smith, 1991).

\section{References}

Bird P., 2003, An updated digital model of plate boundaries: Geochemistry Geophysics Geosystems, v. 4, no. 3, art. no. 1027, doi:10.1029/ 2001 GC000252.

Calais, E., DeMets, C., and Nocquet, J.M., 2003, Evidence for a post-3.16Ma change in Nubia Eurasia North America plate motions?: Earth and Planetary Science Letters, v. 216, no. 1-2, pp. 81-92.

Calais, E., Dong, L., Wang, M., Shen, Z., and Vergnolle, M., 2006, Continental deformation in Asia from a combined GPS solution: Geophysical Research Letters, v. 33, no. 24, art. no. L24319.

Chamot-Rooke, N., and Rabaute, A., 2006, Plate Tectonics from Space: Commission for the Geological Map of the World, first Edition, Paris, scale 1:50.000.000.

Créteaux, J.F., Soudarin, L., Cazenave, A., and Bouillé, F., 1998, Present-day tectonic plate motions and crustal deformations from the DORIS space system: Journal of Geophysical Research, v. 103, no. 12, 30167-30181.

Delescluse, M., and Chamot-Rooke, N., 2007, Instantaneous deformation and kinematics of the India-Australia Plate: Geophysical Journal International, v. 168, no 2, pp. 818-842.

DeMets, C., Gordon, R.G., Argus, D.F., and Stein, S., 1990, Current plate motions: Geophysical Journal International, v. 101, no. 2, pp. 425-478.

DeMets, C., Gordon, R.G., Argus, D.F., and Stein, S., 1994, Effect of recent revisions to the geomagnetic reversal time scale on estimates of current plate motions: Geophysical Research Letters, v. 21, no. 20, pp. 2191-2194.

DeMets, C., Jansma, P.E., Mattioli, G.S., Dixon, T.H., Farina, F., Bilham, R., Calais, E., and Mann, P., 2000, GPS geodetic constraints on CaribbeanNorth America plate motion: Geophysical Research Letters, v. 27, no. 3 , pp. $437-440$

Engdahl, E.R., Van der Hilst, R.D., and Buland, R.P., 1998, Global teleseismic earthquake relocation with improved travel times and procedures for depth determination: Bulletin of the Seismological Society of America, v. 88 , no. 3 , pp. $722-743$.

England, P., and Molnar, P., 2005, Late Quaternary to decadal velocity fields in Asia: Journal of Geophysical Research, v. 110, no. 12, art. no. B12401.

Flesch, L.M., Haines, A.J., and Holt, W.E., 2001, Dynamics of the IndiaEurasia collision zone: Journal of Geophysical Research, v. 106, no. 8, pp. 16435-16460.

Flesch, L.M., Holt, W.E., Silver, P.G., Stephenson, M., Wang, C.Y., and Chan, W.W., 2005, Constraining the extent of crust-mantle coupling in central Asia using GPS, geologic, and shear wave splitting data: Earth and Planetary Science Letters, v. 238, no. 1-2, pp. 248-268.

Ghosh, A., Holt, W.E., Flesch, L.M., and Haines, A.J., 2006, Gravitational potential energy of the Tibetan Plateau and the forces driving the Indian plate: Geology, v. 34, no. 5, pp. 321-324.

Holt, W.E., Chamot-Rooke, N., Le Pichon, X., Haines, A.J., Shen-Tu, B., and Ren, J., 2000, Velocity field in Asia inferred from Quaternary fault slip rates and Global Positioning System observations: Journal of Geophysical Research, v. 105, no. 8, pp. 19185-19209.

Kreemer, C., and Chamot-Rooke, N., 2004, Contemporary kinematics of the southern Aegean and the Mediterranean Ridge: Geophysical Journal International, v. 157, no. 3, pp 1377-1392.

Kreemer, C., Holt, W.E., and Haines, A.J., 2003, An integrated global model of present-day plate motions and plate boundary deformation: Geophysical Journal International, v. 154, no. 1, pp 8-34.

Le Pichon, X., 1968, Sea floor spreading and continental drift: Journal of Geophysical Research, v. 73, no. 12, 3661-3697.

Le Pichon, X., 1991, Introduction to the publication of the extended outline of Jason Morgan's April 17, 1967 American Geophysical Union Paper on "Rises, Trenches, Great Faults and Crustal Blocks": Tectonophysics, v. 187 , no $1-3$, pp. 1-22.

McClusky, S., Balassanian, S., Barka, A., Demir, C., Ergintav, S., Georgiev, I., Gurkan, O., Hamburger, M., Hurst, K., Kahle, H., Kastens, K., Kekelidze, G., King, R., Kotzev, V., Lenk, O., Mahmoud, S., Mishin, A., Nadariya, M., Ouzounis, A., Paradissis, D., Peter, Y., Prilepin, M., Reilinger, R., Sanli, I., Seeger, H., Tealeb, A., Toksoz M.N., and Veis, G., 2000, Global Positioning System constraints on plate kinematics and dynamics in the eastern Mediterranean and Caucasus: Journal of Geophysical Research, v. 105, no. 3, 5695-5719.
Morgan, W.J., 1968, Rises, trenches, great faults, and crustal blocks: Journal of Geophysical Research, v. 73, no. 6, 1959-1982.

Sella, G.F., Dixon, T.H., and Mao, A.L., 2002, REVEL: A model for Recent plate velocities from space geodesy: Journal of Geophysical Research, v. 104, no. 4, art. no. 2081.

Shen, Z.K., Lu, J.N., Wang, M., and Bürgmann, R., 2005, Contemporary crustal deformation around the southeast borderland of the Tibetan Plateau: Journal of Geophysical Research, v. 110, no. 11, art. no. B11409.

Socquet, A., Vigny, C., Chamot-Rooke, N., Simons, W., Rangin, C., and Ambrosius, B., 2006, India and Sunda plates motion and deformation along their boundary in Myanmar determined by GPS: Journal of Geophysical Research, v. 111, no. 5, art. no. B05406.

Vigny, C., Huchon, P., Ruegg, J.-C., Khanbari, K., and Asfaw, L.M., 2006, Confirmation of Arabia plate slow motion by new GPS data in Yemen: Journal of Geophysical Research, v. 111, no. 2, art. no. B02402.

Vigny, C., Simons, W.J.F., Abu, S., Bamphenyu, R., Satirapod, C., Choosakul, N., Subarya, C., Socquet, A., Omar K., Abidin, H.Z., and Ambrosius, B.A.C., 2005., Insight into the 2004 Sumatra-Andaman earthquake from GPS measurements in southeast Asia: Nature, v. 436, no. 7048, pp. 201-206.

Wang, Q., Zhang, P.Z., Freymueller, J.T., Bilham, R., Larson, K.M., Lai, X., You, X.Z., Niu, Z.J., Wu, J.C., Li, Y.X., Liu, J.N., Yang, Z.Q., and Chen, Q.Z., 2001, Present-day crustal deformation in China constrained by global positioning system measurements: Science, v. 294, no. 5542, pp. 574-577.

Wessel, P., and Smith, W.H.F., 1991, Free software helps map and display data: EOS Transactions, American Geophysical Union, v. 72, p. 441.

\section{Relevant web sites}

ITRF2005

http://itrf.ensg.ign.fr/ITRF_Solutions/2005/ITRF2005.php

GSRM v1.2

http://gsrm.unavco.org/intro

Plate boundaries

http://www.ig.utexas.edu/research/projects/plates/plates.htm

Basemap

http://topex.ucsd.edu/WWW_html/srtm30_plus.html

ftp://topex.ucsd.edu/pub/srtm30_plus/README.txt

\section{To order}

\section{Plate Tectonics from Space}

Mercator Projection \& Polar stereographic for North and South Poles Equatorial scale: $1: 50000000$

Total surface of the map: $99 \times 67 \mathrm{~cm}$

(C) CCGM-CGMW 2006

Price: 10 Euro

To order this map: www.ccgm.org - ccgm@club-internet.fr

\section{Nicolas Chamot-Rooke}

Cnrs UMR8538 - Ecole normale supérieure,

Laboratoire de Géologie,

24 rue Lhomond,

75005 Paris,

France

\section{Alain Rabaute}

Geosubsight - Ecole normale supérieure,

Laboratoire de Géologie,

24 rue Lhomond,

75005 Paris,

France 